\title{
PRODUCTIVE CHARACTERISTICS OF AGE-3 BROOD BROWN TROUT (SALMO TRUTTA) REARED IN THE CONDITIONS INDUSTRIAL AQUACULTURE
}

\author{
L. Haloyan, terteryan2009@mail.ru, Institute of Fisheries NAAS, Kyiv \\ A. Mruk, amruk@ukr.net, Institute of Fisheries NAAS, Kyiv \\ A. Kucheruk, anna-kycheryk@ukr.net, Institute of Fisheries NAAS, Kyiv \\ L. Terteryan, 040169@ukr.net, Institute of Fisheries NAAS, Kyiv
}

Purpose. Study and analysis of productive and reproductive parameters of brood brown trout reared in the conditions of industrial aquaculture with the use of feeding with specialized artificial feeds.

Methodology. Fish rearing was performed using a technology traditional for rainbow trout. Biological evaluation of fish was performed on live material according to the scheme developed by I. F. Pravdin (1966) for salmonids. Fish were anesthetized with "Propiscin". Metric parameters were measured with the aid of a ruler and caliper. Fish weight was determined on electronic balances. Eggs were preserved in a 4\% formalin solution, weight of individual eggs was determined with the aid of torsion balances, egg diameter with a caliper. The duration of spermatozoid motility in males was determined under a microscope under $10 \times 40$ magnification with the aid of a stopwatch, sperm concentration was determined in a Goriaev chamber. Multiple regression analysis was performed in JMP IN 4 (SAS Institute). The factor was considered significant if $p<0.05$.

Findings. Brood brown trout reared on specialized artificial feeds had following productive parameters: mean body weight of age-3 fish was $458 \mathrm{~g}$ in males and $453 \mathrm{~g}$ in females. Mean working fecundity of age-3 fish as 1847 eggs, mean relative working fecundity was 3971 eggs, the mean qualitative parameters of which were: weight of $61.5 \mathrm{~g}$, diameter of $74.7 \mathrm{~mm}$. The reproductive characteristics of age-3 males was high - mean fecundity was 1391 million sperm cells, their motility was $35 \mathrm{sec}$.

Originality. For the first time we reared a stock of brood brown trout in industrial conditions with the use of feeding with specialized artificial feeds.

Practical value. The obtained results are a component of the development of a complex technology of salmonid fish rearing with an objective to broad the assortment of valuable gourmet products and to justify the measures on artificial reproduction of brown trout in rivers of the Carpathian region.

Keywords: brood brown trout, working fecundity, relative working fecundity, productivity.

\section{PROBLEM STATEMENT AND ANALYSIS OF LAST ACHIEVEMENTS AND PUBLICATIONS}

The share of salmonids in total amounts of the marketable products of Ukrainian aquaculture enterprises is characterized by low values (1500 tons/year); however, it showed some trends for an increase during last years. The main object of salmonid culture is rainbow trout Oncorhynhus mykis W., which composes $99 \%$, a very little amount is brook trout Salvelinus fontinalis, however, during last years, fish culturists returned to the rearing of native species such as brown trout Salmo trutta morfa fario L.

(C) L. Haloyan, A. Mruk, A. Kucheruk, L. Terteryan, 2017 
The historical facts show that until the middle of the last century, brown trout was the most common fish in mountain rivers of the Carpathian region, Crimea and even upper Dnieper River [1, 2].

According to its biology, the brown trout is demanding for environmental conditions that contributed to a drastic decline of its populations during the second half of the last century due to a number of human-induced factors. The human impacts are manifested not only as the pollution of rivers and excessive harvest of this valuable fish but in the majority of cases as a complete destruction of the reproductive generations, which become the most vulnerable and accessible. However, the most negative effect is manifested as the excessive deforestation, which is done without observing the generally accepted rules, which include the prohibition of log trailing without protective measures, work on rivers during fish spawning run and egg incubation, etc. The negative effects of these works resulted in significant silting of spawning grounds and consequently in the destruction and deterioration of natural rivers bottoms (optimal fraction of which should not be less than 5-10 mm, it allows water to wash fish eggs evenly during their incubation) that brought the natural reproduction to naught. The current state of brown trout is on the edge of survivability and to be listed in the Red Book of Ukraine, the number of its populations dropped by 13.4 times, while the biomass dropped by 42 times according to retrospective information [3, 4].

In particular, the current trend aimed at searching alternate energy sources draw the attention of investors to mountain rivers as the most cost-effective technology for energy production. Although the hydropower industry is a renewable source of energy without carbon dioxide release into the atmosphere, its role in the mitigation of the effects of climate change is limited. However, hydropower plants have a negative effect on aquatic ecosystems: dam construction, withdrawal of significant amounts of water into derivation pipelines, installation of these pipes result in the disturbance of water flow equilibrium and changes of stream channels that in its turn causes soil shears and erosion processes. These effects were confirmed by already existing mini hydro power plants on the Tereblia, Krasna, Tur'ya, Black Cheremosh and other rivers.

The program of the development of hydropower industry on Carpathian rivers planned to build almost 550 small hydropower plants. Thirty four mini hydro power plants are planned only for Verkhovyna district. It means that more than five hundred Carpathian rivers will be placed into pipes and channels for many kilometers and in such a way will be lost for the nature, and as result, their hydrobiocenoses will be destroyed $[5,6]$. However, these programs do not envisage mitigation measures aimed at the preservation and restoration of the fauna of these rivers.

The effective replenishment of natural populations is possible only by artificial propagation, the prerequisite of which is the creation of domesticated replacementbrood stocks, the exploitation of which will allow regular release of viable fish seeds into rivers that will ensure the biological diversity of Carpathian rivers [7, 8, 9].

In particular, the diversification of aquaculture species structure due to valuable native salmonids will contribute to the diversification of the assortment of specialty products for domestic consumers. 


\section{HIGHLIGHT OF THE EARLIER UNRESOLVED PARTS OF THE GENERAL PROBLEM. AIM OF THE STUDY}

Rearing of table brown trout is more developed in France, preserved in Germany, Switzerland, and Italy. In Poland and Slovakia, the brown trout is reared for artificial stocking into local rivers and streams.

The brown trout in reared mainly in natural water bodies. In Western Europe, in particular in France, Czech Republic, Slovakia, and Italy, this fish is artificially reared in rivers and streams for sport fishing and is an object of pond aquaculture. Cultivation and rearing of the brown trout is carried out in pond fish farms of Western Ukraine. Rearing of the brown trout is not sufficiently profitable, however, it is widely recognized that dishes prepared of this fish are tastier and healthier and are recommended for dietetic nutrition not only for adults but also for children [2-4].

Taking into account relatively low fecundity of the brown trout as well as widespread poaching during their spawning run, the restoration of the stocks of this valuable fish by natural way is very slow. In order to increase the number of brown trout stocks in natural water bodies, urgent measures aimed at its protection are necessary, first of all more strict protection and increase in the amounts of artificial propagation.

\section{MATERIALS AND METHODS}

The material for the study were brood fish reared from natural brood brown trout from the Cheremosh River. The weight of wild females was from 80 to $190 \mathrm{~g}$, the majority of fish was 4-5 years old. The working fecundity of females fluctuated from 227 to 1012 eggs. The fertilized eggs were incubated at water temperature of $8{ }^{\circ} \mathrm{C}$ for 36 days, these parameters in natural conditions are $0.2-3.0^{\circ} \mathrm{C}$ and 180 days. The obtained juveniles were grown to sexual maturity in industrial conditions of the tank fish farm "Ishkhan". Fish were fed with specialized artificial feeds for salmonids manufactured by "Aller Aqua". The protein content in the feeds was no lower than $42 \%$ and fat no lower than $22 \%$. Water temperature during rearing did not fall below $8{ }^{\circ} \mathrm{C}$ in the winter and did not exceed $16{ }^{\circ} \mathrm{C}$ in the summer. Fish rearing was based on the technology commonly accepted for rainbow trout [10]. Biological evaluation of fish was performed using live material according to the scheme developed by I. F. Pravdin (1966) for salmonids [11]. Fish anesthesia was done using "Propiscine" manufactured in Poland at a concentration of $0.5 \mathrm{ml} / \mathrm{l}$. Metric parameters were measured by a ruler and caliper. Fish weight was determined using electronic balances. Eggs were preserved in a $4 \%$ formalin solution, weight of eggs was determined with the aid of torsion balances and their diameter by a caliper. The duration of sperm cell motility in males was determined under a microscope with 10x40 magnification, stop watch, sperm cell concentration was determined in a Goryaev chamber.

For the determination of the significance degree of parameters, which can be used in the evaluation of reproductive quality of brood brown trout as well as for finding relationships between them, we analyzed the entire array of data of fish lengths, working and relative fecundity, largest body depth, largest body circumference, egg weight, egg diameter, total egg weight. A linear regression analysis was used, which was done in JMP (SAS Institute). The factor was considered to be significant if $p<0.05$ [12]. 


\section{STUDY RESULTS AND THEIR DISCUSSION}

The valuation of the brown trout brood stock was performed at the end of November. On the $2^{\text {nd }}$ December, a technical and biological evaluation of 50 specimens of fish ( 25 females and 25 males) was done and sexual products were collected for the reproduction purpose, tables 1,2 .

Mean weight of females was relatively high; however, the difference between minimum and maximum body weights was $781 \mathrm{~g}$.

Mean weight of males was very variable and insignificantly higher than that of females, however, the difference between minimum and maximum body weights was lower than that of females: $618 \mathrm{~g}$.

Table 1. Characteristics of age-3 females, $\mathbf{n}=\mathbf{2 5}$

\begin{tabular}{|c|c|c|c|c|c|c|c|c|c|}
\hline & \multirow{2}{*}{$\begin{array}{l}\begin{array}{c}\text { Fish } \\
\text { weight, }\end{array} \\
\text { g }\end{array}$} & \multirow{2}{*}{$\begin{array}{l}\text { Fish } \\
\text { length, } \\
\text { cm }\end{array}$} & \multirow{2}{*}{$\begin{array}{c}\text { Condition } \\
\text { factor }\end{array}$} & \multirow{2}{*}{$\begin{array}{l}\text { Slender- } \\
\text { ness } \\
\text { index }\end{array}$} & \multirow{2}{*}{$\begin{array}{l}\text { Circum- } \\
\text { ference } \\
\text { index }\end{array}$} & \multicolumn{2}{|c|}{ Body depth } & \multicolumn{2}{|c|}{$\begin{array}{c}\text { Body } \\
\text { circumference }\end{array}$} \\
\hline & & & & & & Min & Max & Min & Max \\
\hline $\mathbf{M}$ & 453 & 34 & 0.96 & 4.04 & 183.2 & 73.3 & 78.4 & 31.4 & 183.2 \\
\hline $\mathbf{m}$ & 139.4 & 3.43 & 0.20 & 0.35 & 24.7 & 7.4 & 10.8 & 3.3 & 24.7 \\
\hline$\delta$ & 27.99 & 0.68 & 4.03 & 7.02 & 4.94 & 1.47 & 2.15 & 0.66 & 4.94 \\
\hline $\mathrm{Cv}$ & 30.8 & 10.0 & 20.9 & 8.69 & 13.5 & 10.1 & 13.8 & 10.6 & 13.5 \\
\hline \multicolumn{10}{|c|}{ Variation range } \\
\hline Max & 824 & 41 & 1.5 & 5.4 & 0.63 & 10.0 & 4.0 & 24.0 & 9.0 \\
\hline Min & 43 & 27 & 0.6 & 3.7 & 0.41 & 6.0 & 2.8 & 14.0 & 55 \\
\hline
\end{tabular}

The obtained results demonstrated that the growth of the brown trout in controlled conditions had significant advantages compared to fish from natural water bodies. One of the main factors, which contributed to it, was balanced regular feeding with specialized artificial feeds. The protein content in the artificial feed was $45 \%$, fat $15 \%$. The feed conversion ratio in first spawned brood fish was 1.6.

Table 2. Characteristics of age-3 males, $\mathbf{n}=\mathbf{2 5}$

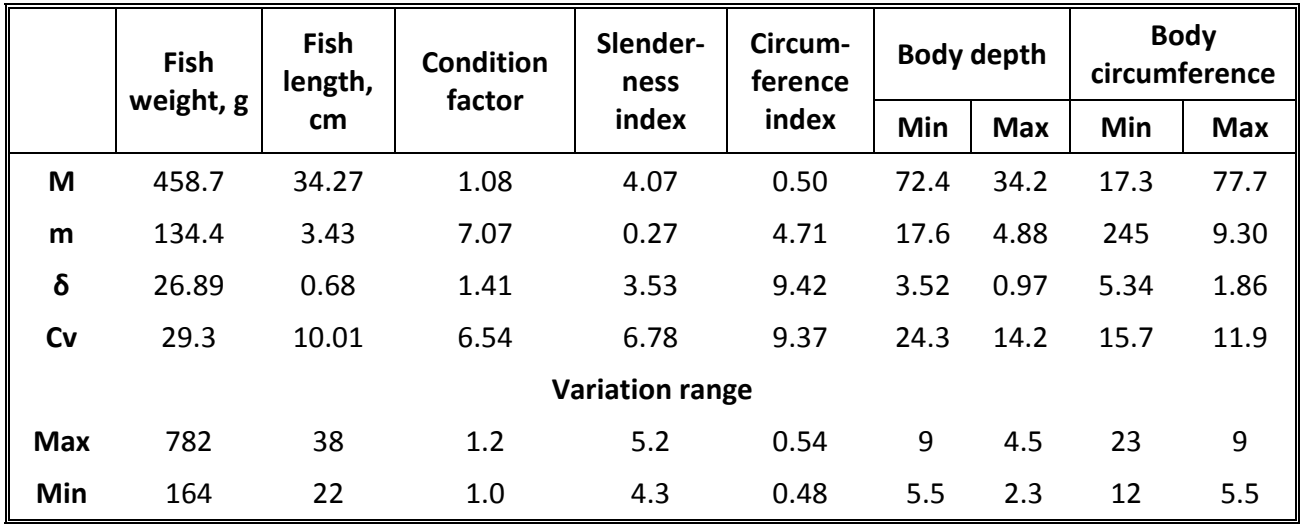

The brown trout was grown with the use of artificial feeds had significantly higher results of weight accumulation compared to brown trout from natural water bodies. 
E.g., the age-3-4 brown trout from the Irshava River had a mean weight of $135.1 \mathrm{~g}$ with a range of 53-279 g [2], while age-3 specimens in our experiment reached the maximum weight of $824 \mathrm{~g}$ with a mean weight of $460 \mathrm{~g}$ that was 3.4 times more. The monitoring of brown trout growth in industrial conditions was irregular. E.g., on the first year of life, the weight gain did not exceed $11 \mathrm{~g}$ and the mean weight was $8.4 \mathrm{~g}$; on the second year of life, weight gain increased and its mean value was $127.3 \mathrm{~g}$ [13]. The highest body weight gain was observed on the third year of life (fig. 1), when fish weight increased by $333 \mathrm{~g}$ and was on average $460 \mathrm{~g}$.

In our opinion, this is due to the gradual acquisition of the conditioned reflex to artificial conditions of their keeping at high stocking densities (according to norms of industrial rearing - 25-30 kg/m $\mathrm{m}^{2}$ ) and feeding with artificial feeds.

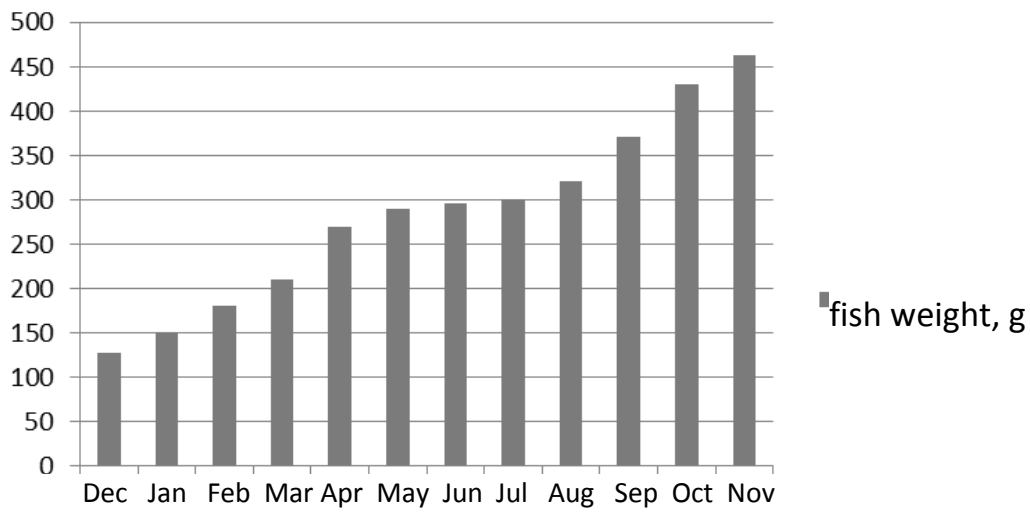

Fig. 1. Body weight gain of brown trout during a year (from the age 2 to 3 )

\section{Reproductive characteristics of brown trout.}

The studied fish were 3 years old and were used for artificial reproduction for the first time. Their reproductive characteristics are presented in table 3 . Working fecundity of females were almost twice higher than that of females from natural populations [1]. The variability of working fecundity was high because the samples were random and it depended on individual peculiarities of the studied females.

Table 3. Reproductive characteristics of age-3 brown trout females, $\mathbf{n}=\mathbf{2 5}$

\begin{tabular}{|c|c|c|c|c|c|c|c|c|}
\hline & \multirow{2}{*}{$\begin{array}{c}\text { Fish } \\
\text { weight, } \mathrm{g}\end{array}$} & \multirow{2}{*}{$\begin{array}{c}\text { Egg } \\
\text { weight, } g\end{array}$} & \multirow{2}{*}{ Ls, $* \mathrm{~cm}$} & \multicolumn{2}{|c|}{ Fecundity, eggs } & \multicolumn{2}{|c|}{ Egg parameters } & \multirow{2}{*}{$\begin{array}{c}\text { Fecundity } \\
\text { index }\end{array}$} \\
\hline & & & & working & relative & $\mathrm{P}, \mathrm{mg} * *$ & $\mathrm{D}, \mathrm{mm}^{* * *}$ & \\
\hline$M$ & 453.7 & 114 & 34 & 1847 & 3971 & 61.47 & 4.7 & 244.4 \\
\hline m & 139.4 & 44 & 3.43 & 672.4 & 513 & 5.93 & 3.93 & 33.00 \\
\hline$\delta$ & 27.9 & 8.8 & 0.68 & 134.49 & 102 & 1.18 & 0.19 & 6.7 \\
\hline Cv & 30.8 & 38.4 & 10.0 & 36.40 & 129 & 9.65 & 4.14 & 14.18 \\
\hline $\min$ & 824 & 230 & 41 & 745 & 2949 & 51 & 4.4 & 164 \\
\hline $\max$ & 43 & 38 & 27 & 3918 & 4977 & 73 & 5.1 & 235.6 \\
\hline
\end{tabular}

Notes.* fish fork length, ** egg weight, *** egg diameter 
The reproductive characteristics of age-3 males were also high (table 4). The ejaculate volume was $6.8 \mathrm{~cm}^{3}$ with a range of $3.5-12.2$, the mean sperm cell concentration was $206.4 \mathrm{million} / \mathrm{ml}(97-316)$. The duration of sperm cell motility was $35.6 \mathrm{sec}(19.5-56.4)$ (table 4).

Table 4. Reproductive characteristics of age-3 brown trout males

\begin{tabular}{|c|c|c|c|c|c|}
\hline & $\begin{array}{c}\text { Weight, } g \\
n=25\end{array}$ & $\begin{array}{l}\text { Ejaculate } \\
\text { volume } \\
\mathrm{n}=25, \mathrm{ml}\end{array}$ & $\begin{array}{l}\text { Sperm cell concen- } \\
\text { tration, million } / \mathrm{ml}^{3} \\
\qquad \mathrm{n}=7\end{array}$ & $\begin{array}{c}\text { Working fecundity } \\
\text { of sperm cells } \\
n=7\end{array}$ & $\begin{array}{c}\text { Duration of sperm } \\
\text { cell motility, sec } \\
n=10\end{array}$ \\
\hline $\mathbf{M}$ & 458.7 & 6.8 & 206.4 & 1391.7 & 35.6 \\
\hline$m$ & 134.4 & 2.23 & 69.2 & 472.1 & 14.1 \\
\hline$\delta$ & 26.89 & 0.44 & 26.8 & 178.4 & 5.3 \\
\hline Cv & 29.31 & 32.6 & 33.55 & 33.9 & 39.7 \\
\hline \multicolumn{6}{|c|}{ Range } \\
\hline Max & 654 & 11.2 & 316 & 1860 & 56.4 \\
\hline Min & 164 & 3.5 & 97 & 542 & 19.5 \\
\hline
\end{tabular}
million.

Mean working fecundity was high -1391 sperm cells with a range of 1860-542

Table 5. Linear regression results

\begin{tabular}{|c|c|c|c|c|}
\hline \multirow{2}{*}{ Parameters } & \multicolumn{2}{|c|}{ Linear regression coefficients } & \multirow{2}{*}{$\mathbf{F}$} & \multirow{2}{*}{$\mathbf{p}$} \\
\hline & a & b & & \\
\hline Body length - egg weight & $-342.80 \pm 41.32$ & $13.32 \pm 1.12$ & 123.60 & $<0.001$ \\
\hline Body weight - egg weight & $-14.94 \pm 13.08$ & $0.29 \pm 0.028$ & 107.60 & $<0.001$ \\
\hline
\end{tabular}

The obtained results of linear regressions (table 5) can be used for predictive assessments of reproductive characteristics of brown trout based on their exterior parameters.

\section{CONCLUSION AND PERSPECTIVES OF FURTHER DEVELOPMENT}

The results of the study within the given project is a reared and domesticated stock of age- 3 brood brown trout.

The analysis of results demonstrated high values of reproductive and productive parameters of the brood brown trout reared in the conditions of industrial technology with the use artificial feeds compared to natural populations. E.g., mean weight of age-3 males and females was $458 \mathrm{~g}$ and $453 \mathrm{~g}$, respectively. Mean working fecundity was 1847 eggs, relative working fecundity was 3971 eggs.

The obtained results indicate on the possibility of the artificial reproduction of brown trout in rivers of the Carpathian region not only for the replenishment of their natural populations but also for rearing this species in this region for broadening the assortment of gourmet products.

\section{BIBLIOGRAPHY}

1. Берг Л. С. Рыбы пресных вод СССР и сопредельных стран / Берг Л. С. - М. : АН CCP, 1949. - T. 3. - 876 c.

2. Устич В. I. Історичні аспекти та перспективи відродження лососівництва в Закарпатті / В. І. Устич, А. І. Мрук // Раціональне використання водних ресурсів 
- необхідний елемент стійкого розвитку : 3-я робоча зустріч Української річкової мережі, с. Осій (Ужгород) 26-29 черв. 2003 р. : матер. — Ужгород : Ліра, 2003. - C. 42-45.

3. Мрук А. І. Сучасний стан та перспективи відтворення цінних лососевих видів риб в Закарпатті / А. I. Мрук, В. І. Устич, І. І. Маслянка // Проблемы воспроизводства аборигенных видов рыб. - К. : Світ рибалки, 2005. - С. 196-200.

4. Мрук А. I. Склад іхтіофауни річки Іршава / А. І. Мрук, В. І. Устич, I. I. Маслянка // Рибогосподарська наука України. — 2009. — № 1(7). - С. 16-21.

5. Movement and summer habitat of brown trout (Salmo trutta) below a pulsed discharge hydroelectric generating station / C. M. Bunt, S. J. Cooke, C. Katopodis [et al.] // Regulated Rivers-Research \& Management. — 1999. — № 15. - P. 395- 440.

6. Мрук А. І. Прогнозований вплив будівництва міні ГЕС на популяції цінних лососевих риб карпатського регіону / А. I. Мрук, А. I. Хандожівська, I. Й. Великопольський // Современные проблемы гидробиологии, перспективы пути и методы решений : III междунар. конф., 17-19 мая 2012 г. : матер. Херсон, 2012. - C. 289-293.

7. Didenko A. Challenges to restoration of salmonids in streams of the Ukrainian part of the Carpathians/ A. Didenko, A. Mruk, S. Kruzhylina // International Workshop on the Restoration of Fish Populations, September 1-4, 2009. — Düsseldorf, Germany. - P. 25.

8. Грициняк И. И. Состояние и перспективы воспроизводства редких и исчезающих пресноводных видов лососевых рыб в Украине / И. И. Грициняк, А. И. Мрук // Воспроизводство естественных популяций ценных видов рыб : Межд. конф., 2022 апр. 2010 г. : тезисы докл. - С-Пб., 2010. - С. 48-50.

9. Didenko A. Conservation and restoration of nativ salmonids in Ukrainian Carpathians: perspectives and challenges / A. Didenko, A. Mruk // Advances in the population ecology of stream salmonids : International symposium, May 17-23, 2010. - Luarca, Asturia, Spain.

10. Правдин И. Ф. Руководство по изучению рыб / Правдин И. Ф. - М. : Пищевая пром-ть, 1966. - $376 \mathrm{c.}$

11. Галасун П. Т. Технологическая инструкция по производству радужной форели в различных типах хозяйств Украины. / Галасун П. Т., Булатович М. А., Борбат М. О. - Львов, 1987. - 17 с.

12. Ramsey F. L. The statistical sleuth: a course in methods of data analysis / F. L. Ramsey, D. W. Shafer. — Duxbury Press, 1997. — 742 p.

13. Моніторинг росту струмкової форелі в індустріальних умовах господарства «Ішхан» / А. І. Мрук, Л. Л. Тертерян, А. І. Хандожівська [та ін.] // Рибогосподарська наука України. - 2013. - № 1. - С. 31-38.

\section{REFERENCES}

1. Berg L. S. (1949). Ryby presnykh vod SSSR i sopredel'nykh stran. Moskva : AN SSR.

2. Ustych, V. I., \& Mruk, A. I. (2003). Istorychni aspekty ta perspektyvy vidrodzhennia lososivnytstva $\mathrm{v}$ Zakarpatti. Ratsionalne vykorystannia vodnykh resursiv - neobkhidnyi element stiikoho rozvytku : 3-ia robocha zustrich Ukrainskoi richkovoi merezhi, s. Osii (Uzhhorod) 26-29 cherv. 2003 r. Uzhhorod : Lira, 42-45.

3. Mruk, A. I., Ustych, V. I., \& Maslianka, I. I. (2005). Suchasnyi stan ta perspektyvy vidtvorennia tsinnykh lososevykh vydiv ryb v Zakarpatti. Problemy vosproizvodstva aborigennykh vidov ryb, 196-200.

4. Mruk, A. I., Ustych, V. I., \& Maslianka, I. I. (2009). Sklad ikhtiofauny richky Irshava. Rybohospodarska nauka Ukrainy, 1(7), 16-21.

5. Bunt. C. M., Cooke, S. J., Katopodis, C., \& McKinley, R. S. (1999). Movement and summer habitat of brown trout (Salmo trutta) below a pulsed discharge hydroelectric generating 
station. Regulated Rivers-Research \& Management, 15, 395-440.

6. Mruk, A. I., Khandozhivska, A. I., \& Velykopolskyi, I. I. (2012). Prohnozovanyi vplyv budivnytstva mini HES na populiatsii tsinnykh lososevykh ryb karpatskoho rehionu. Sovremennye problemy gidrobiologii, perspektivy puti $i$ metody reshenyi : III mezhdunar. konf., 17-19 maia 2012 g. Kherson, 289-293.

7. Didenko, A., Mruk, A., \& Kruzhylina, S. (2009). Challenges to restoration of salmonids in streams of the Ukrainian part of the Carpathians. International Workshop on the Restoration of Fish Populations, September 1-4. Düsseldorf, Germany, 25.

8. Gritsinyak, I. I., \& Mruk, A. I. (2010). Sostoyanie i perspektivy vosproizvodstva redkikh i ischezayushchikh presnovodnykh vidov lososevykh ryb $\mathrm{v}$ Ukraine. Vosproizvodstvo estestvennykh populyatsiy tsennykh vidov ryb : mezhd. konf., 20-22 aprelya 2010. Sankt-Peterburg, 48-50.

9. Didenko, A. \& Mruk, A. (2010). Conservation and restoration of nativ salmonids in Ukrainian Carpathians: perspectives and challenges. Advances in the Population Ecology of Stream Salmonids : International Symposium, May 17-23, 2010. Luarca, Asturias, Spain.

10. Pravdin, I. F. (1966). Rukovodstvo po izucheniyu ryb. Moskva : Pishchevaya prom-t'.

11. Galasun, P. T., Bulatovich, M. A., \& Borbat, M. O. (1987). Tekhnologicheskaya instruktsiya po proizvodstvu raduzhnoy foreli $v$ razlichnykh tipakh khozyaystv Ukrainy. L'vov.

12. Ramsey, F. L., \& Shafer, D. W. (1997). The statistical sleuth: a course in methods of data analysis. Duxbury Press.

13. Mruk, A. I., Terterian, L. L., Khandozhivska, A. I., \& Terterian, L. A. (2013). Monitorynh rostu strumkovoi foreli v industrialnykh umovakh hospodarstva "Ishkhan". Rybohospodarska nauka Ukrainy, 1, 31-38.

\section{ПРОДУКТИВНАЯ ХАРАКТЕРИСТИКА З-ГОДОВЫХ ПРОИЗВОДИТЕЛЕЙ РУЧЬЕВОЙ ФОРЕЛИ (SАLMО TRUTTA), ВЫРАЩЕННЫХ В УСЛОВИЯХ ИНДУСТРИАЛЬНОЙ АКВАКУЛЬТУРЫ}

л. л. Галоян, terteryan2009@mail.ru, Институт рыбного хозяйства НАAН, г. Киев

А. И. Мрук, amruk@ukr.net, Институт рыбного хозяйства НАAН, г. Киев

А. И. Кучерук, anna-kycheryk@ukr.net, Институт рыбного хозяйства НАAН, г. Киев

Л. А. Тертерян, 040169@ukr.net, Институт рыбного хозяйства НАAН, г. Киев

Цель. Исследования и анализ продуктивных и репродуктивных показателей производителей ручьевой форели, выращенных в условиях индустриальной аквакультуры с использованием кормления искусственными специализированными кормами.

Методика. Выращивание рыб проводили по технологии, принятой для радужной форели. Биологическую оценку рыб проводили на живом материале по схеме, разработанной И. Ф. Правдиным (1966) для лососевых рыб. Анестезию рыб проводили препаратом «Прописцин». Метрические показатели измеряли с помощью линейки и итангенциркуля. Массу рыб определяли на электронных весах. Икринки фиксировали в 4\% растворе формалина, массу икринок определяли с помощью торсионных весов, диаметр штангенциркулем. Продолжительность подвижности сперматозоидов у самцов определяли под микроскопом при увеличении 10х40, с помощью секундомера, концентрацию спермиев определяли в камере Горяева.

Использовался множественный регрессионный анализ, который выполнялся $в$ программе JMP IN 4 (SAS Institute). Фактор считался значимым при $p<0,05$.

Результаты. Производители ручьевой форели выращенные на специализированных искусственных кормах имели следующие показатели продуктивности: средняя масса тела 3-летних производителей ручьевой форели составляла 458 г у самцов и 453 г у самок. 
Средняя рабочая плодовитость 3-летних самок ручьевой форели была 1847 икринок, средняя относительная рабочая плодовитость - 3971 икринок, средние качественные показатели которых имели следующие значения: масса 61,5 м2, диаметр 74,7 мм. Репродуктивная характеристика трехлетних самцов ручьевой форели была высокой - средняя плодовитость составляла 1391 млн спермиев, их подвижность длилась 35 с.

Научная новизна. Впервые было выращено стадо производителей ручьевой форели в индустриальных условиях с использованием кормления искусственными специализированными кормами.

Практическая значимость. Полученные результаты являются составной частью разработки комплексной технологии по выращиванию лососевых рыб, с целью расширения ассортимента ценной деликатесной продукции и обоснование мероприятий по искусственному воспроизводству ручьевой форели в реках Карпатского региона.

Ключевые слова: ручьевая форель, рабочая плодовитость, относительная рабочая плодовитость, производительность.

\section{ПРОДУКТИВНА ХАРАКТЕРИСТИКА З-РІЧНИХ ПЛІДНИКІВ СТРУМКОВОÏ ФОРЕЛІ (SALMO TRUTTA), ВИРОЩЕНИХ В УМОВАХ ІНДУСТРАЛЬНОї АКВАКУЛЬТУРИ}

л. Л. Галоян, terteryan2009@mail.ru, Інститут рибного господарства НАAН, м. Київ А. І. Мрук, amruk@ukr.net, Інститут рибного господарства НАAН, м. Київ

А. І. Кучерук, anna-kycheryk@ukr.net Інститут рибного господарства НАAН, м. Київ Л. А. Тертерян, 040169@ukr.net, Інститут рибного господарства НАAН, м. Київ

Мета. Дослідження та аналіз продуктивних та репродуктивних показників плідників струмкової форелі вирощених в умовах індустріальної аквакультури з використанням годівлі итучними спеціалізованими кормами.

Методика. Вирощування риб проводили за технологію, прийнятою для райдужної форелі. Біологічну оцінку риб проводили на живому матеріалі за схемою, розробленою І. Ф. Правдіним (1966) для лососевих риб. Для анестезії риб використовували препарат "Пропісцін», польського виробництва. Метричні показники вимірювали лінійкою, кравецькою стрічкою та штангенциркулем. Масу плідників визначали на електронних вагах. Ікринки фіксували у 4\% розчині формаліну, масу ікринок визначали за допомогою торсіонних терезів, діаметр штангенциркулем. Тривалість рухливості сперміїв у самців визначали секундоміром під мікроскопом за збільшення 10х40, концентрацію сперміїв визначали у камері Горяєва.

Використовувався множинний регресійний аналіз, який виконувався в програмі JMP IN 4 (SAS Institute).

Результати. Плідники струмкової форелі вирощені на спеціалізованих штучних кормах мали наступні показники продуктивності: середня маса 3-річних плідників струмкової форелі складала 458 г у самців та 453 г у самиць. Середня робоча плодючість 3-річних самиць струмкової форелі становила 1847 ікринок, середня відносна робоча плодючість 3971 ікринку, середні якісні показники яких мали наступні значення: маса 61,5 мг, діаметр 4,7 мм. Репродуктивна характеристика трирічних самців струмкової форелі була високою середня плодючість складала 1391 млн сперміїв, їх рухливість тривала 35,6 с.

Наукова новизна. Вперше в Україні було вирощено доместиковане стадо плідників струмкової форелі в індустріальних умовах $з$ використанням годівлі штучними спеціалізованими кормами.

Практична значимість. Отримані результати $\epsilon$ складовою частиною розробки комплексної технології з вирощування лососевих риб, з метою розширення асортименту цінної делікатесної продукції та обгрунтування заходів зі штучного відтворення струмкової форелі в річках Карпатського регіону.

Ключові слова: струмкова форель, робоча плодючість, відносна робоча плодючість, продуктивність. 